\title{
Making Immigration Work: How Britain and Europe Can Cope with their Immigration Crises (The Government and Opposition/Leonard Schapiro Lecture, 2015)
}

\begin{abstract}
This article provides a review of the economic, demographic and welfare effects of immigration in contemporary Europe. It argues that the economic benefits of migration are small but positive, its welfare effects minimal if not non-existent, and its demographic effects modest but real. It then provides a series of recommendations for governing migration policy in Europe: keeping the borders open but controlled; keeping employment high and income support low, and keeping speech free but fair. The most important policy recommendation centres on work: immigration policy will only work when immigrants work.
\end{abstract}

Keywords: immigration, demography, Islam, free speech, integration, assimilation

IMMIGRATION IS AMONG THE DEFINING ISSUES OF OUR TIME. FOR OVER five years, since June 2010, UK voters have ranked immigration a close second to the economy (and ahead of health) as the "most important issue facing the country' (YouGov 2015). Anti-immigrant parties in the UK, France and Denmark enjoy levels of support of around 25 per cent. By comparison, France's National Front achievement in 1988 of 15 per cent support caused a near-panic among the country's political elite. In the Netherlands, Denmark and Norway, anti-immigrant parties have altered the party systems and supported governments. And in the UK, the United Kingdom Independence Party's (UKIP) electoral support caused alarm within the Conservative Party and enabled it to force a rightward push on positions such as immigration and Britain's membership of the

* Randall Hansen is Director of the Centre for European, Russian and Eurasian Studies at the Munk School of Global Affairs and Professor in the Department of Political Science at the University of Toronto. Contact email: r.hansen@utoronto.ca. 
European Union. The mass influx of refugees and asylum seekers over the summer and into the autumn of 2015 rejuvenated the moribund anti-Islamic Patriotic Europeans against the Islamization of the Occident (PEGIDA) movement in Germany, increased the far right's share of the vote to over 30 per cent in Austrian elections and helped bring the nationalist right to power in Poland. ${ }^{1}$

Islam and Muslims in Europe, the product mostly of early post-war migrations, have since 2001 been associated with a debate that is polarized and ugly. Radical Islam, Islamism, jihadism or violent extremism appeal chiefly to a minority of Muslims who have - and let us be frank here - signed up to a death cult. The 13 November 2015 atrocities in Paris were only the most recent in a long series of jihadist plots. At the same time, this tiny minority is interpreted by sections of the far right, media and public opinion as representative of the whole of the complex and varied forms of Islam found in Europe. In addition, state breakdown in the Middle East, for which NATO, the US, Britain and France bear much responsibility, has produced outflows of refugees on an unprecedented scale. In 2014, the last year for which we have complete data, the number of forcibly displaced migrants reached 60 million, a historical high. The closest precedent is the period of mass expulsion - in Europe, South and East Asia following the Second World War. Fully 55 per cent (5.5 million people) of 2014's refugees came from only five countries: Afghanistan, Iraq, Syria, Somalia and Sudan. Yet only a minority, around 3 per cent, of the total global population of forced migrants, is able to lodge an application for asylum; the rest are in refugee camps or cities in the global south (UNHCR 2014). ${ }^{2}$

All of this is embedded in Europe's ongoing economic crisis, characterized by stagnating economic growth, high public debt and unemployment levels that threaten a lost generation of European youth (Hansen and Gordon 2014). These are thus troubled times, even by our low, post-2008 standards. Rather than adding to the gloom, however, I hope to use this article to articulate a number of propositions that, together, suggest that Europe's immigration crisis is not only manageable but, with the right approach, solvable. My remarks will proceed in four steps: first, a brief historical overview of post-war migration to Europe; second, a discussion of the socioeconomic costs and benefits of migration; third, a discussion of Islam in Europe; and fourth, a series of political and policy recommendations for making immigration work. 
HOW WE GOT HERE

If traced back far enough, all European societies can be viewed as the product of migration in the form of tribal movements across Europe. In more recent history, from the mid-nineteenth century to today, five waves of migration have buffeted European societies. The first, called the 'great unmixing', lasted from 1830 to the mid-1920s (Brubaker 1995; Marrus 1985: 41). It was driven by nationalism, imperial dissolution and the emergence of nation states in southeastern Europe. The dissolution of the Habsburg and Ottoman empires, and the resulting emergence of Greece, Bulgaria, Romania, Serbia, Montenegro and, finally, Turkey, resulted in the expulsion of millions of people, Muslim and Christian alike. As in all expulsions, these movements resulted in great suffering, many deaths and, in the case of the Armenians, the near-eradication of an entire people. The second wave began in the mid-1930s, as Stalin forcibly deported Koreans, Germans, Finns, Greeks, Tatars and Buddhist and Muslim minorities mostly to Central Asia and Siberia. These deportations continued during the Second World War as Hitler joined Stalin in the expulsion of millions of Slavs and then added his own horrible contribution through the annihilation of the Jews of Europe. The expulsion of some 12 million Germans from all countries east of the Federal Republic's current borders marked the end of this second wave, by which point the deep diversity that had characterized Central Europe was over forever. The Jewish and German intelligentsia and merchant class that had dominated Central Europe's great cities were gone, and they were replaced by a chiefly peasant class that moved in from the countryside.

Western Europe's post-war economic recovery launched the third wave of migration. From the late 1940s to 1973, low-skilled, chiefly male migrants came to work in Western Europe's then-booming industries of coal, steel, cars, textiles and so forth. They came through two schemes - colonial citizenship and immigration schemes in Britain, France and the Netherlands, and guest-worker schemes in the rest of northern Europe - but they were driven by the same economic imperative (Hansen 2000; Hollifield et al. 2014; Joppke 1998). Political crises (Algeria halted migration to France following racist attacks) and above all the OPEC oil crisis brought the third wave to an end as one country after another instituted stops on migration (Hollifield et al. 2014; Schain 2012). This effort at 
migration control failed in that it generated a new wave of migration: forced to choose between remaining or permanently returning, most migrants remained and then brought their families. Most migration from the early 1970s until the early 1990s was family migration, through which chiefly low-skilled family members joined chiefly low-skilled men in Western Europe. The final, fifth wave, from the early 1990s to today, has been the most varied. Family immigration has continued, but asylum seekers, skilled migration, illegal migrants and, since 2004, EU migration from states that joined the Union after 2004 have increased sharply. In the UK, migrants since 2005 have been better skilled and better educated than the average UK population, with important fiscal effects. At the time of writing, Europe appears to be on the verge of a sixth wave of migrants - namely, refugees chiefly but not only from the Middle East - but it is too early to make any definitive pronouncements.

Today, France, Germany, Italy, Spain and the UK have the largest numbers of immigrants, as shown in Figure 1.

Over the last 10 years, the long-established receiving countries of Britain and Germany have taken in many immigrants, but Italy and above all Spain (with arrivals following the booms and busts of the Spanish economy) have joined them as major destinations (see Figure 2).

\section{LIES, DAMN LIES AND STATISTICS: THE SOCIAL AND ECONOMIC BENEFITS (AND COSTS) OF MIGRATION}

Few debates in politics (though there are admittedly some serious challengers) are characterized by such a large gap between rhetoric and reality as the migration debate, and the political left and right bear roughly equal guilt. The anti-immigration right would have us believe that large-scale immigration imposes great costs on the receiving society: congestion, spiralling welfare bills, housing shortages and wage depression for society's poorest members (Collier 2013). The pro-immigration left would have us believe that immigration creates great wealth and, indeed, that national prosperity depends on it (Clemens 2011). Anyone reading these debates for the first time would have the impression that immigration points to both the road to hell and the gates to heaven.

Rather unremarkably, these extreme claims are false. But the point runs deeper than this: almost every argument made in favour 


\section{Figure 1}

Foreign Resident Population 2014 by EU-28 Member State

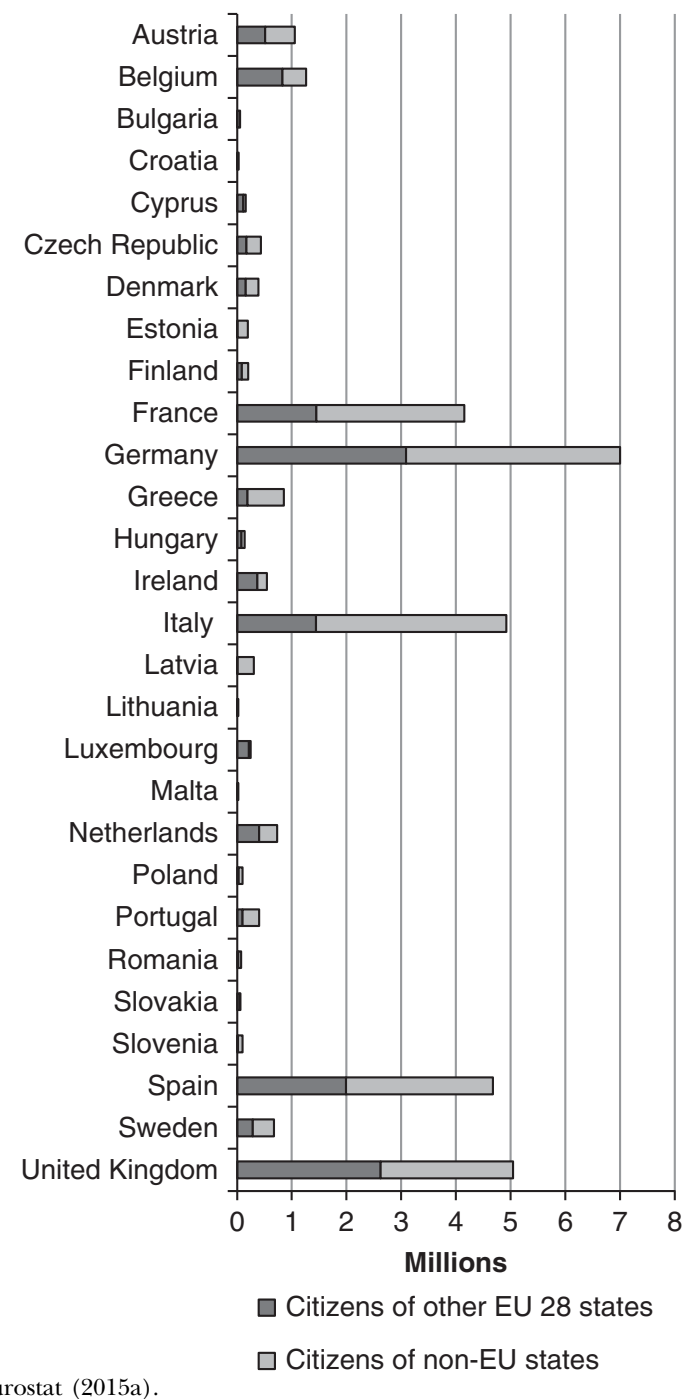

Source: Eurostat (2015a).

and against migration is false. The most common of these are as follows:

1. Immigration is either a great benefit or a great cost to the economy. False. 


\section{Figure 2}

Total Number of Long-term Immigrants Arriving into the Reporting Country
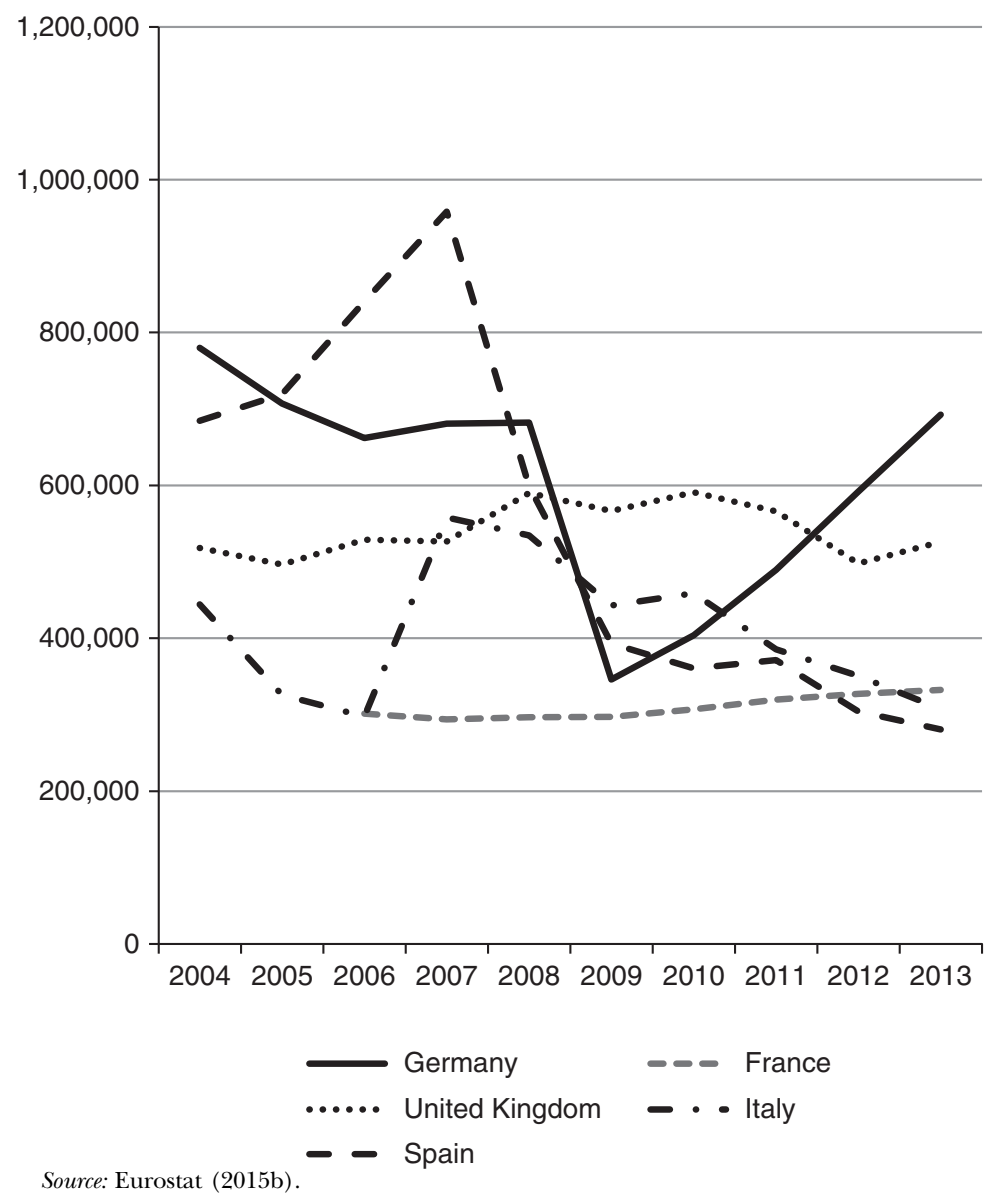

2. Immigration is a threat to the welfare state. False.

3. Immigration is either a solution to our demographic challenges or has no effect whatsoever on them. Both claims are false.

\section{Immigration and the Economy}

Beginning with the first, the economic effects of immigration are, in macro terms, small and are a function of (a) the skill level of the 
migrants and (b) the generosity of state assistance. Where migrant skills complement those of natives (that is, where they are different), migrants do not compete with native workers for jobs, and both employment and the wages of some domestic workers will rise (Martin 2015). Where the skills overlap (for instance, in agricultural or construction sectors), there is likely to be wage depression and native unemployment or withdrawal from particular sectors (Martin 2015). This should be clear to anyone attempting to find a nativeborn American taxi driver in New York, an industry in which gruff working-class New Yorkers were once as common as the cockney in a London cab. Whatever happens, the numbers are small. The most comprehensive survey of the economic costs and benefits of immigration to the world's greatest immigration country, the US, concluded in the mid-1990s that migration produced a net economic benefit worth US $\$ 8$ billion, or about one tenth of 1 per cent of a national income of US $\$ 8$ trillion, or approximately 10 days' economic growth (Smith and Edmonston 1997). An adjustment in the frequency or length of coffee breaks could produce the same benefit with no migration.

On point (b), the higher the level of state assistance, and the more immigrants draw on it, the lower the benefit of migration. Thus in California and New York, states with relatively generous welfare programmes and high levels of unskilled immigration, immigration results in a higher cost for the state than in other states, such as Texas, that have less generous services (Martin 2015: 106). The above-cited mid-1990s study concluded that US-born California taxpayers paid $\$ 2,700$ more in taxes than they received in services, whereas immigrants received $\$ 2,700$ more than they paid (Martin 2015: 107).

Immigration makes countries neither rich nor poor, but it does change them. The largest effects of migration are distributional in nature. The chief economic benefit of immigration is wage depression, so when immigrants' skill sets overlap with those of natives, unskilled migration will reduce the wages of the unskilled native workers (thus increasing inequality). Skilled migration, on the other hand, will reduce the wages of skilled workers (thus increasing equality) (Martin 2015). Thus, immigration to the UK from 1997 to 2005 depressed wages for the bottom twentieth percentile, increased them slightly for the top fortieth percentile and produced a modestly positive overall wage effect (Dustmann et al. 2013: 146-7). 
The effects are small: a maximum wage decrease of approximately 0.6 per cent at the fifth wage percentile and a maximum wage increase of approximately 0.6 per cent at the fiftieth percentile (Dustmann et al. 2013: 160). In the US, the above-mentioned mid-1990s study concluded that immigration reduced wages by 3 per cent from US $\$ 13.00$ per hour to US $\$ 12.60$ (Martin 2015: 93). The reductions resulted in two other distributional effects: (i) to capital (employers pay lower wages) and (ii) to the immigrants themselves (employment expands as wages drop, and immigrants capture most of the private gain). Finally, within federations there are spatial distributional effects: immigrants pay more taxes to the US federal government but collect most services (education, justice and health care) at the state level; immigration is thus fiscally net positive for the federal government and fiscally negative for the states (Martin 2015: 106). It is worth noting that the same is true for many Americans, who consume the same services locally and pay more taxes federally.

Given the complexities of immigration and the multiple variables at play, generalization is difficult, but Philip Martin (2015: 96) gets it right when he concludes that "[a]dding immigrants to the labor force expands GDP by slightly lowering wages and increasing returns to capital, with most of the increase in national income accruing to immigrants and employers'.

\section{Immigration and Welfare}

Over the last decade, some of the most passionate debate has concerned the relationship between immigration and welfare. Is it true, as Milton Friedman concluded (without feeling the need to run a regression), that 'it's just obvious that you can't have free immigration and a welfare state?' The debate has been so impassioned because, in a Berlinian way, it suggests that two outcomes of which progressives want to see more - immigration and welfare - are mutually exclusive. And progressives, much more than conservatives, are accustomed to having their cake and eating it too.

Immigration might threaten the welfare state and support for it through the effect of diversity on trust. Robert Putnam concluded in a widely anticipated and well-researched piece (drawing on extensive US census data) that trust declines as diversity increases: in diverse San Francisco and Los Angeles, only 30 per cent of respondents 
say they trust their neighbours, whereas the figure for ethnically homogeneous communities in North Dakota and South Dakota is between 70 and 89 per cent (Putnam 2007: 148). The finding holds for both intra-group and inter-group trust, and Putnam controls for 17 factors, including age, ethnicity, education, affluence, region, crime and population density (Putnam 2007: 151-2). The decline in trust is only indirectly related to welfare, and Putnam makes relatively little of it. He rather sees less volunteering, less charity, fewer friends and (rather anachronistically in the light of the internet) more time in front of the television as the consequences of lower trust. But writers such as Paul Collier, David Goodhart and David Miller have hypothesized that lower levels of trust will translate into less willingness to support the necessary wealth transfers to other citizens and/or residents (Collier 2013; Goodhart 2004, 2013; Miller 2004, 2005, 2008). Those holding this position certainly have evidence they can cite: historically, the great expansion in US welfare in the 1930s and the 1960s occurred in periods of relatively low immigration (indeed, effectively none in the 1930s) (Goodhart 2004). Today, some of the most vocal opposition to immigration is grounded in what one scholar calls welfare chauvinism and emerges in Scandinavian states, which have among the most generous welfare states in Europe (Favell 2014: 287).

The conclusions on trust are incontrovertible, and our confidence (trust?) in them should be reinforced by the fact that they are reached not by an anti-immigration conservative but rather by a progressive who, with an eye to their political implications, hesitated to publish his findings. But does a decline in trust result in a decline in support for the welfare state? It does not. Social scientists have found no consistent relationship between multicultural policies (an official recognition of diversity) and either (a) reduced support for the redistribution of wealth or (b) decreased redistributive social expenditure (Crepaz 2006: 108; Evans 2006; Joppke 2010: 76). On the contrary, redistributive spending increased in two of the most diverse and immigrant-friendly countries on the planet: Australia and Canada (Joppke 2010: 76). Although he certainly has an ideological horse in the race, the quantitative evidence supports the conclusion of Will Kymlicka (2009: 239) that, based on 21 OECD countries from 1978 to 1998, '[t]here was simply no evidence that countries with large foreign-born populations had more trouble sustaining and developing their social programs over these three decades than countries with small immigrant communities'. 
As so often in politics, the US seems to constitute an exception. There, the presence of large black and Latino populations does correlate positively with lower levels of social spending (Hero and Preuhs 2006: 121-6; Joppke 2010: 76). As the US is the world's largest immigration country, this finding matters, but it matters less than one might think at first glance. Once political institutions (proportional representation electoral systems correlate with higher welfare spending since they favour left-wing parties) are controlled for, the strength of the causal relationship drops by 50 per cent (Alesina and Glaeser 2004: 76). We only have suggestions accounting for the remaining 50 per cent: people are more generous to members of their own racial group (which would confirm Miller and Collier's fears); there is a uniquely American tendency to stigmatize the poor as lazy; and/or politicians have an incentive to construct the poor as lazy in order to secure attention and votes (Joppke 2010: 77). The last point might be partially institutional: the US's weak and polarized party system encourages individual initiative and the adoption of attention-grabbing contrarian opinions in a manner that is largely unthinkable in Westminster democracies. But all these explanations overlook a further, possibly decisive, factor: in America, welfare is targeted, whereas in (northern) Europe, it is universal. That is, major American welfare programmes such as AFDC (Aid to Families with Dependent Children - replaced in 1996 by Temporary Assistance for Needy Families) and Medicaid have been reserved for and associated with the poor. In northern Europe, health, unemployment and pension programmes are universal (though status segmented in France, Austria and Germany), and universal programmes always enjoy more support than targeted ones. The main universal US programme, Social Security, is the sacred cow of American fiscal policy. Universal health care in the UK and Canada enjoys similar extremely high levels of public support. The point here is that the way in which the programme is delivered and who benefits from the programmes matters far more than immigration and diversity, if the last two matter at all.

\section{Immigration and Demography}

If immigration's economic effects are small and chiefly distributional, what of its much-vaunted demographic ones? Europe has a very low 
birth rate, at 1.5 children per woman (the replacement rate is 2.1) (Eurostat 2015c). ${ }^{3}$ Can immigration ward off the deleterious effects of ageing and declining populations (increasing health and pension costs, increased debt per capita in the context of population decline)? It has become fashionable in social-scientific circles, and to a degree in political circles, to dismiss immigration's demographic effects for three reasons. First, although many migrant groups have higher birth rates when they arrive in Western countries, their birth rates tend to converge with national averages over the medium term (Camarota and Zeigler 2015; Woldemicael and Roderic 2010). Second, the influxes of immigration required to maintain workingage ratios are massive and therefore politically intolerable. Germany would, according to UN estimates, need 3.4 million net migrants per year between 1995 and 2050 to keep a support ratio of 4.4 (the number of workers below 14 and over 65 divided by those of working age) (UN Population Division 2001). Third - and this is the real intellectual advance - immigrants age like everyone else, making them an eventual cost rather than a benefit for the exchequer.

There is naturally something to these points, but they are overstated. Models created by the UN Population Division in 2001 demonstrate that even relatively modest levels of migration lead to substantial differences. In a Germany without immigration, population would fall from 81.7 million in 1995 to 55.8 million in 2050 (UN Population Division 2001: Germany). With 240,000 migrants per year (an achievable goal), population would fall to 73.3 million, though the support ratio would be halved in the absence of compensating measures (raising the retirement age, for instance). At the same time, whereas a problem deferred is not a problem solved, it is preferable to no deferral. Imagine, for instance, that immigration delays population decline by 25 years. This is itself worthy (indeed, solving a pensions crisis for 25 years would be regarded as a great accomplishment), but it also buys time for governments to enact other measures: raising the retirement age, the female employment rate and productivity. A gradual decline in population is easier to manage than a sudden plunge.

There is a further reason for optimism: global demographic developments may work in Europe's favour. An ageing Europe will inevitably experience labour shortages, especially in low-skilled care and service industries: cleaning, shopping, the preparation of meals, help getting in and out of the bath, and so on. If these are assumed 
through institutional care, the costs are likely to be enormous. As this demographic shift occurs, a very different scenario will play out in Turkey, large parts of Africa, the Middle East and South Asia: young and growing populations whose economies - even successful ones like Turkey's - will struggle to produce enough work. There will thus be a complementarity of labour shortage and labour supply.

\section{THE POLITICS OF IMMIGRATION}

Although the precise economic, social and demographic effects of immigration can be debated, one thing cannot: the management of immigration is only possible if immigration has broad public support, or at least indifference. If clear majorities consistently oppose current migration levels, then it is both a normative and political crisis: consistently ignoring the wishes of the electorate is hard to reconcile with liberal democracy, and doing so risks an ugly political backlash of the sort seen in the UK in the late 1960s (the time of Enoch Powell), Germany in the early 1990s (when refugee hostels were firebombed), the US in the 2000s (when vigilantes guarded the US-Mexican border) and, to a degree, the UK again since 2004.

Until recently, public opinion research provided little prospect of avoiding the normative or political challenge. A well-cited comparative analysis attempted to find out where immigrants were popular and concluded that they were popular nowhere: 'Western attitudes towards immigration vary over time, but the most widely documented and pervasive finding is that sizable proportions of national publics, usually majorities, either oppose increasing current immigration levels or favor reducing them' (Freeman 1997).

More recent research suggests a more complicated picture (IOM 2015). A Gallup/IOM study $(\mathrm{n}=183,772)$ offers three new conclusions of direct importance for migration management. First, the volume of migration correlates with opinions on migration, but it does not correlate with a negative attitude towards migration. Second, the percentage of respondents globally who want immigration kept at the same levels or to be increased (42.1 per cent) is greater than those who want it decreased ( 34.5 per cent). Third, immigration is more popular in countries with high levels of immigration. In the top 10 receiving countries, 46.8 per cent of adults believe that immigration levels should remain as they are or increase, which is 
almost 5 per cent higher than the global average (though 47.5 per cent of people desire a decrease). Immigration is most popular in the countries with the highest percentage of temporary workers: the Gulf Cooperation Council countries (with the exception of Kuwait and Bahrain). The other findings - for example, that the young (Russia excepted) and the educated support immigration more than the old and less educated - are consistent with previous research (Freeman et al. 2012). Within Europe, majorities in Germany and Scandinavia wish to see the same or higher levels of immigration, whereas immigration is particularly unpopular in southern Europe and the UK. ${ }^{4}$

In accounting for public attitudes to migration, there is a basic distinction between (relatively) static and dynamic factors. The overall educational level and age ratios (the percentage of old to young people) in the population are relatively static factors: they change only slowly, over decades. Economics, however, is a dynamic factor: economies can vacillate quickly, at times with surprising speed, between recession, boom and stagnation. At the time of writing, northern Europe was enjoying solid economic growth, while southern Europe remained mired in recession.

Economics might partially explain the northern/southern European contrast: northern Europe is doing well economically, southern Europe poorly, and those respondents who regard economic conditions as 'good' are indeed more likely to support migration (IOM 2015). But this cannot explain the UK, which at the time of writing was enjoying solid economic growth. Rather, what ties southern Europe and the UK is a failure of migration management: Italy, Spain and Greece, because of geography, and the UK, because of the decision in 2004 to allow immediate access for A8 workers, all created the impressions in their electorates that they have lost control of their borders. And such a loss of control invariably results in a public backlash: all the above-cited examples occurred when the state had little control over migration: because of relative openness to the Commonwealth in the UK, because of asylum law in Germany, and because of the challenges facing the US in controlling its southern border. The particularly sharp reaction provoked in the most pro-immigration countries, such as Australia and Canada, by the arrival of boats containing small numbers of illegal migrants can only be explained by the symbolic assault on sovereignty contained in arrivals by boat: landing in front of the cameras, they declare border controls to be ineffective. 


\section{ISLAM, ISLAMOPHOBIA AND FREE SPEECH}

Since 11 September 2001, the global immigration debate has centred, often to an excessive degree, on Muslims and Islam, and it has occurred against the backdrop of three post-9/11 developments. The first is an upsurge in anti-Islamic sentiment and a mobilization by some political parties and individual politicians around the threat posed by Islam to Europe and European values. The second development is an attendant upsurge in anti-Semitism across Europe, including physical attacks on Jews. The evidence is not conclusive, but Muslims, and above all young Muslim men, appear to be overrepresented among those committing these attacks. And the third development, which is directly relevant to what happened in Paris in January 2015, is an attack by an unholy alliance of religious extremists and progressive thinkers on the principles of free speech.

Islamophobia is a disputed concept, denied by the political right (or, worse still, justified as a logical response to Muslim behaviour) and exaggerated by the political left. As ever, clarity is found in the numbers. Large-N survey data show that Europeans indeed view Islam with greater hostility than they view Judaism or Christianity, but this hostility remains confined to a minority of Europeans. Moreover, other surveys, conducted after $9 / 11$ and the Madrid and London bombings, show very positive attitudes towards Muslims among French and British nationals (though not German ones).

Surveys do not, however, tell the full story, and political discourse constraints have relaxed to the point where politicians will blithely make sweeping comments about Muslims that would not be politically tolerable in the case of Jews or Christians. This is seen most clearly in the case of the far right (Geert Wilders in the Netherlands, Marine le Pen in France), but also among mainstream commentators and politicians. The successful Eurabia literature both exaggerated the demographic effects of Muslim migration and fertility and it constructed Islam as a foreign religion (a construction mystifying to anyone with even an inkling of Habsburg and south-eastern European history). And when Thilo Sarrazin, a centrist Social Democratic politician and former finance minister of Berlin, wrote a bestselling book on the subject, he became the darling of the talk-show circuit (though he also received much criticism on it) and 
made a pile of money on the basis of highly derogatory comments about Muslims (Sarrazin 2012).

Anti-Semitism in Europe has increased in tandem with Islamophobia. In the Paris murders, five Jews were killed because they were Jews. For years, national authorities have reported increased anti-Semitic incidents such as vandalism of Jewish graveyards and synagogues and assaults on Jews wearing religious dress. In the summer of 2014, a group of what appeared to be North African men tried to launch what can only be described as a modern pogrom, including an effort to ransack a synagogue, in a Jewish neighbourhood in Paris (Faye 2014).

The third development, an assault on free speech principles, had a longer pedigree, and it began with the Rushdie affair in 1988. The basic events replayed themselves, naturally with some variations, during the Danish cartoon controversy of 2006 and following the Charlie Hebdo murders of 2015. In all three instances, artists produced works which some deemed offensive to Islam. Protests, threats (including Iran's support for Rushdie's murder from 1989 to 1998) and violence followed. Secular commentators split into basically two camps: those who offered robust defences of free speech, including the right to offend (Hansen 2006; O'Leary 2006), and those who argued that, although they in principle supported free speech, artists and intellectuals should avoid offending Muslims (Carens 2006; Chambers 2015; Modood 2006, 2015).

\section{THE WAY FORWARD}

To summarize, immigration has modest economic effects but important distributional ones; increasing diversity through immigration reduces trust but this does not translate into lower support for the welfare state; and public support depends on a strong economy and a controlled border. These are general features - truths, if you will - of immigration policy. Within Europe, rising anti-Semitism, Islamophobia and violent assaults on free speech - in the UK in 1989-90, Denmark in 2006 and Paris in 2015 - have been contextual features of immigration policy and politics.

Against this backdrop, I would like to conclude by making some recommendations for the governance of migration policy. At the risk 
of being overly schematic, these can be organized around three headings:

\section{Keep the Doors Open but the Borders Controlled}

Immigration, both skilled and unskilled, holds great promise for Europe and Europeans. The case in favour of skilled immigration is clear, and no one can rationally dispute it. Unskilled immigration is more complicated, as it can impose a fiscal cost on society, but this (a) has to be set against its benefits and (b) can be managed. In the former, the lower costs and expanded availability of unskilled labour has a direct impact on the quality of life of the middle classes: more affordable cleaners, contractors and nannies bring what might otherwise be luxuries into the reach of middle-income earners; this frees up middle classes from domestic labour and allows them to engage in higher productivity work and makes it easier for middleclass women to enter the labour force. Far from being exploitative, such arrangements are good for the workers themselves as they earn far more than they could hope to earn in their countries of origin. Huge numbers of Latinos came and come across the border to the US because there are jobs and because they want those jobs: 11.6 million Mexicans live in the US, making up 28 per cent of all US immigration (Zong and Batalova 2015).

Properly managed, even unskilled immigration can produce a positive net economic benefit. The best evidence suggests that migration to the UK since 1995, which involves more unskilled immigration than skilled, has produced a net fiscal gain, and that post-2004 intra-EU migration to the UK has also produced a gain. Christian Dustmann and Tommaso Frattini (2013: 19), who undertook the UK study, speculate that there is a productivity gain through migration because migrants are paid less than they should be, given their skill level (around 15 per cent less). Their conclusion is consistent with widespread evidence that, in all immigrant countries, migrants make less than non-migrants with similar qualifications. And what this means is that migrants produce not one but two productivity gains. The largest, as the migration-sceptic Paul Collier has noted, accrues to the migrants themselves (Collier 2013: 114). But, since immigrants are paid less than they should be for their skill set, a smaller productivity gain (through low immigrant wages) accrues to everyone else, which in turn raises societal wages. Looking 
at data from 1997 to 2005 (that is, before A8 and A10 migration), Dustmann and his colleagues conclude that every 1 per cent increase in immigration resulted in wage growth of between 0.1 per cent and 0.3 per cent and a reduction for the bottom twentieth percentile, peaking at 0.6 per cent for the bottom fifth (Dustmann et al. 2013: 165). UK average adult national income was approximately $£ 22,152$ between 1997 and 2005, which means that immigration increased wages overall by $£ 332.28$ (assuming an average of 0.15 per cent; wage data from Dobbs 2006). In 2013, the poorest 10 per cent were paid between $£ 6,000$ and $£ 7,000$. Averaging this to $£ 6,500$, it means that a generous (as 2013 figures are used) measure of the annual wage loss to the poorest is $£ 39$ annually. The result is quite clear: tax and spending adjustments could transfer the wage loss back to the twentieth percentile, and even increase their wages while leaving a net fiscal gain from European Economic Area immigration. The public expenditure effects were also positive: between 1995 and 2011, European Economic Area migrants paid into the fiscal system 4 per cent more than they received in benefits, with a positive net effect of $£ 4$ billion (since 1999, the figures have been much more positive: they contributed £22.1 billion in revenue - paying 34 per cent more into the fiscal system than they took out) (Dustmann and Frattani 2013: 27).

The picture is not always so rosy. Indeed, analysis of non-European Economic Area migrants shows a net fiscal cost of $£ 75$ billion over the same period. This figure partly reflects transitory effects (nonEuropean Economic Area migrants are much more likely to have children than European Economic Area ones) but also greater reliance on state benefits: non-European Economic Area migrants are more likely than European Economic Area migrants to receive benefits (European Economic Area migrants are 4.7 per cent less likely than natives of the same age to draw state benefits or tax credits, whereas non-European Economic Area migrants are 0.8 per cent more likely) (Dustmann and Frattani 2013: 22). European Economic Area migrants are 3 per cent less likely than natives to live in social housing, whereas non-European Economic Area ones are 3 per cent more likely). And whereas the employment rate for European Economic Area immigrants has been slightly higher than that of natives (75 per cent vs. 70 per cent), it has been substantially lower for non-European Economic Area immigrants (62 per cent, all 2011 figures). 
(Dustmann and Frattani 2013: 19-20). And this in turn brings us to a second recommendation.

\section{Keep Income Support Low and Employment High}

As migration can swing easily from a (low) net benefit to a (low) net cost, it is essential to bring and to keep immigrants in work. Work is, in effect, the basis of migrant integration in the US, Australia and Canada. Too often in Europe, they are integrated into welfare. And welfare dependency is costly both to society and, if you will, to the soul: in the absence of work, there is no hope of dignity and autonomy in a market society. ${ }^{5}$

There are naturally different ways to move people into work. At the bottom end of the scale, income assistance can be reduced with an eye to nudging people into work. 'Agenda 2010' helped reduce Germany's high unemployment and gave the chronically unemployed an opportunity to enter the job market by placing time limits on more generous unemployment benefits and by providing work that pays a small amount (€1 to €2.50) above welfare benefits. More broadly, income assistance for the unemployed cannot be set above the market wage. Doing so can only encourage unemployment, as William Beveridge, who can hardly be qualified as a reactionary, recognized. Such suggestions may provoke the ire of progressive scholars. There are nonetheless good reasons for thinking that badly paid work, above all if it is transitional, is better than no work. In the case of first-generation immigrants, there is a mutual benefit in a system of benign exploitation: when immigrants are paid less than natives, but more than they would earn at home, the receiving country receives a productivity capture.

By the second generation, few, least of all the children themselves, would or should tolerate lower pay than their peers, and maximizing both the number of well-paid jobs and minority access to those jobs should be the primary goal. Achieving this aim is at once simple and extraordinarily difficult. It is simple because there is a broad consensus that the prerequisites for access to better jobs and higher income (as well as higher labour productivity and overall societal wealth) are education and skills training. Better schools, colleges and universities, more access to them for minorities, and higher educational achievement will translate into more employment and better earnings. In countries such as Germany and 
Switzerland, where much training is organized through apprenticeships supplied by employers, expanded access to these opportunities will deliver the same results. Germany actually has a particular advantage in that it has an intact industrial base (unlike the UK, for instance) and thus job opportunities for skilled immigrants who would not secure places at universities (and who often have no interest in them).

At the same time, this recipe for success is extraordinarily difficult because training and education are expensive, and governments everywhere are more likely to put funds into social programmes that benefit the old (health, pensions) than into training and education for the young (The Economist 2014). In addition, success in education requires extraordinarily hard work, and much of the initiative will have to come from immigrants themselves. The school system can, of course, do much, through concentrated resources on local language training, closing bad schools in poor neighbourhoods and redistributing students to better schools. It can also provide diversity training to teachers who might otherwise out of ignorance stream minority students away from academic programmes (there is anecdotal evidence of this sort of dynamic in Germany).

\section{Keep the Speech Free but Fair}

Anti-Semitism, Islamophobia and an assault on free speech are all features of contemporary European politics. Many would dispute this formulation and see only one or two of them as real problems. Necessarily oversimplifying, the right downplays Islamophobia and emphasizes anti-Semitism and threats to free speech (O'Neil 2015), whereas the left emphasizes Islamophobia while downplaying threats to free speech (Modood 2015) and, to a lesser degree, anti-Semitism. ${ }^{6}$ All three are, however, real and they require a common response: a robust assault on extremism.

In the case of Islamophobia and anti-Semitism, both legal and rhetorical responses are required. In the former (and this is the easy part), current legal prohibitions on anti-Jewish and anti-Muslim discrimination should be robustly applied (and should be seen to be applied). In the latter, those who argue that Islam is a foreign import incompatible with European values - far-right politicians, commentators such as Bruce Bawer, Mark Steyn and Christopher Caldwell - must be challenged vigorously. The arguments are known and well 
rehearsed, but they need to be repeated: acts of violence are committed by a tiny minority, and we are too inclined in the case of Muslims to associate such violence with the faith itself or with all its believers. By contrast, when Jews or Christians commit acts of violence, we instinctively regard them as lunatics who are unrepresentative of their faith. ${ }^{7}$ Few people believe that Christian fundamentalists shouting 'God hates fags' or Orthodox Jews attacking Palestinian property and hacking down olive trees speak, respectively, for Christianity and Judaism. When the French socialist government published a bill allowing gay marriage (it eventually passed), the most vociferous protests came not from French Muslims but from Roman Catholics, who poured into Paris from the provinces to show, often with homophobic placards, their opposition. ${ }^{8}$ Few thought that they spoke for all Christians, or even all Catholics. Finally, following what we know from contact theory, the more inter-faith interactions (including, importantly, interactions between believers and non-believers) that can be fostered, the less prejudice we will see (Allport 1979). Against this background, moves by governments in Europe to ban the hijab in schools and the burka on the street, though perhaps grounded in concerns for gender equality with which one can sympathize, have been unhelpful and have further encouraged the view that Islam is unwelcome in Europe.

In the aftermath of (and the lead up to) the January 2015 Paris attacks, as in the aftermath of the Rushdie and Danish cartoon affairs, substantial sections of opinion, Islamic and non-Islamic, have held that the publications of caricatures of the Islamic Prophet Muhammed go beyond the viable limits of free speech (Carens 2006; Chambers 2015; Fadel 2015; Marshall 2015; Modood 2006, 2015). This is simply absurd. The right to mock religion, any religion, is so within the bounds of acceptable speech that the fact that there is a debate at all is mystifying. Religious requirements apply to followers of the religion and to no one else; to suggest otherwise is to imply that non-Muslims should internalize Islamic rules. This principle has, however, to apply to everyone: there cannot be restrictions on free speech for one religion and an open season in matters of free speech for another. For this reason, blasphemy laws in European countries, including Germany, the UK and Italy, are an affront to the principle and understandably encourage the view among some Muslims that Europeans operate a double standard in matters of free speech. In this regard, the arrest by French authorities of a virulently 
anti-Semitic comedian, Dieudonné M'bala M'bala, was unwise, however offensive his views.

And what of offence? To be sure, publishing crude caricatures of the Prophet is disrespectful and offensive. Respect, however, is a matter of choice and cannot be mandated: no one has to respect anyone, and many believe that all religions are unworthy of respect. Pious Muslims certainly do not respect philanderers, men who enjoy the delights of gay saunas, or women who like a drink. ${ }^{9}$

The last point raises a further issue. Islam is a large and highly diverse religion; prohibitions of portrayals of the Prophet apply fully only to Sunni and not to Shiite Muslims, and the most religious among them will take the requirement most seriously. All things being equal, the most conservative and orthodox members of any religion are those who will adopt the most literal and uncompromising (and often selective) views of religious texts: compare attitudes towards the Bible among Church of England followers in north London with Pentecostals in the southern US. And what this in turn means is that those most demanding of respect and religious accommodation are least likely to extend it towards others, such as gays and lesbians. That academics and liberal commentators would align themselves with such an illiberal lot is mystifying.

A deferential approach to religious conservatism is also deeply condescending, above all to moderate Muslims, as it suggests that they are somehow not quite as good as the rest of us and need the sort of 'pass' that the liberal academy was unprepared, rightly so, to accord Christian fundamentalists who demanded revisions to the American education curriculum in the 1980s. No less a thinker than the political philosopher Charles Taylor has confidently stated that Muslims cannot understand the distinction between religion and politics (Gutman and Taylor 1994: 62). It is hard to imagine a more patronizing statement.

The 13 November 2015 jihadist attacks on central Paris served to confirm the arguments about free speech developed in this article. The deliberate and indiscriminate slaughter of innocent French civilians, including Muslims, makes it clear that these murders have nothing to do with an absence of respect; they have nothing to do with speech, however offensive or not it may be. They are driven rather by an ideology that understands nothing but death, destruction, fear and theocratic slavery. Once we recognize this fact, we 
will be one step closer to grasping the nature of the challenge to liberal democracy.

\section{CONCLUSION}

To summarize the arguments suggested in this article, immigration produces modest yet positive economic benefits and delays and makes population ageing and decline more manageable. When it is skilled, immigration is welcome everywhere; when it is unskilled, it raises the prospect of providing benefits for both the immigrant (whose wages increase) and the middle classes (who can improve their quality of life through reliance on cheaper labour). Public opinion can be sceptical of immigration, but when borders are controlled and migration managed, immigrants and immigration enjoy much more support. Finally, lower income support and ideally dynamic labour markets can help ensure that migrants are incorporated into work rather than welfare. Beyond getting the political economy of integration right, there is a parallel task of combating three assaults on liberal democratic values in Europe: Islamophobia, anti-Semitism and an assault, often by those who regard themselves as paragons of liberalism, on free speech.

Given my current place of employment, in Toronto, home to the high priests of multiculturalism, it would perhaps be remiss of me to say nothing about the role that multiculturalism has in integrating immigrants. So let me say this: it plays absolutely no role, has nothing to do with the relative success of immigration in Canada and is certainly no model for Europe. Canada's immigration policy, like Australia's, succeeds because it attracts highly skilled migrants and channels them into work. And that is the broadest lesson: immigration works where immigrants work.

\section{ACKNOWLEDGEMENTS}

This article is based on the 2015 Government and Opposition/Leonard Schapiro Lecture, which I gave at the Political Studies Association's annual conference in Sheffield on 31 March 2015. Many thanks to the journal editors Katharine Adeney and Paul Taggart for the invitation and for comments on the lecture and article. For research assistance, I am grateful to Joseph Hawker at the Munk School of Global Affairs. A final word of thanks goes to Jessica Cuthbert-Smith for editing the article.

(C) The Author 2016. Published by Government and Opposition Limited and Cambridge University Press 


\section{NOTES}

130.4 per cent to be exact. See http://orf.at/wahlergebnisse/ooe15.

2 These percentages may have changed with the great influx of refugees in Germany in the last half of 2015, but the numbers are not yet available.

${ }^{3}$ Birth rates vary from a high of 2.01 in France to a low of 1.28 in Portugal; Germany, south and Eastern Europe have the lowest birth rates; France, the UK, Scandinavia and Ireland have the highest.

4 The German data pre-date the great upsurge in refugee arrivals in 2015, which will have reduced German support for immigration.

${ }^{5}$ I owe this point to John Gray.

${ }^{6}$ The Guardian commentator Owen Jones (2015) discussed religious hatred at length in the wake of the Charlie Hebdo attacks without a single mention of anti-Semitism or the Jewish victims.

7 A conversation with Erik Bleich clarified this point.

${ }^{8}$ I owe this observation to Isham Rekiouak, an undergraduate student at the University of Toronto.

${ }^{9}$ A conversation with Christian Joppke clarified this point.

\section{REFERENCES}

Alesina, A. and Glaeser, E.L. (2004), Fighting Poverty in the U.S. and Europe: A World of Difference (Oxford: Oxford University Press).

Allport, G.W. (1979), The Nature of Prejudice (Reading, MA: Addison Wesley Publishing Company).

Brubaker, R. (1995), 'Aftermaths of Empire and the Unmixing of Peoples: Historical and Comparative Perspectives', Ethnic and Racial Studies, 18(2): 189-218.

Camarota, S.A. and Zeigler, K. (2015), 'The Declining Fertility of Immigrants and Natives', Center for Immigration Studies, Washington, DC, http://cis.org/declining-fertility.

Carens, J. (2006), 'Free Speech and Democratic Norms in the Danish Cartoon Controversy', International Migration, 44(5): 34-42.

Chambers, S. (2015), 'Free Speech and Civility in Pluralist Societies', in E.M. Iacobucci and S.J. Toope, After the Paris Attacks: Responses in Canada, Europe, and around the Globe (Toronto: University of Toronto Press): 13-21.

Clemens, M.A. (2011), 'A World without Borders Makes Economic Sense', The Guardian, 5 September.

Collier, P. (2013), Exodus: How Migration is Changing our World (Oxford: Oxford University Press).

Crepaz, M. (2006), "If you Are my Brother, I May Give you a Dime!" Public Opinion on Multiculturalism, Trust, and the Welfare State', in K. Banting and W. Kymlicka (eds), Multiculturalism and the Welfare State (New York: Oxford University Press): 92-117.

Dobbs, C. (2006), Patterns of Pay: Results of the Annual Survey of Hours and Earnings 1997 to 2005 (London: Office of National Statistics).

(C) The Author 2016. Published by Government and Opposition Limited and Cambridge University Press 
Dustmann, C. and Frattini, T. (2013), The Fiscal Effects of Immigration to the UK, CREAM Discussion Paper 22/13 (London).

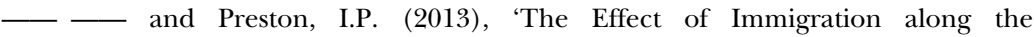
Distribution of Wages', Review of Economic Studies, 80: 145-73.

The Economist (2014), 'A Billion Shades of Grey,' 26 April.

Eurostat (2015a), 'Population on 1 January by Five Year Age Group, Sex and Citizenship', http://ec.europa.eu/eurostat/en/web/products-datasets/-/MIGR_POP1CTZ. - (2015b), 'Immigration by Five Year Age Group, Sex and Citizenship', http:// ec.europa.eu/eurostat/en/web/products-datasets/-/MIGR_IMM1CTZ.

(2015c), 'Fertility Statistics', http://ec.europa.eu/eurostat/statistics-explained/ index.php/Fertility_statistics.

Evans, G. (2006), 'Is Multiculturalism Eroding Support for Welfare Provision?', in K. Banting and W. Kymlicka (eds), Multiculturalism and the Welfare State (New York: Oxford University Press): 152-76.

Fadel, M. (2015), 'A Tale of Two Massacres: Charlie Hebdo and Utoya Island', in E.M. Iacobucci and S.J. Toope (eds), After the Paris Attacks: Responses in Canada, Europe, and Around the Globe (Toronto: University of Toronto Press): 29-42.

Favell, A. (2014), 'The Fourth Freedom: Theories of Migration and Mobilities in "Neo-liberal" Europe', European Journal of Social Theory, 17(3): 275-89.

Faye, O. (2014), 'Sarcelles sous le choc des violences antisémites', Le Monde, 22 July, www.lemonde.fr/societe/article/2014/07/22/sarcelles-sous-le-choc-des-violencesantisemites_4461039_3224.html.

Freeman, G.P. (1997), 'Immigration as a Source of Political Discontent and Frustration in Western Democracies', Studies in Comparative International Development, 32(3): 42-64.

- Hansen, R. and Leal, D. (2012), Immigration and Public Opinion in Europe and North America (with D. Leal and G.P. Freeman) (New York: Routledge).

Goodhart, D. (2004), 'Too Diverse?: Is Britain Becoming Too Diverse to Sustain the Mutual Obligations behind a Good Society and the Welfare State?', Prospect, 20 February.

- (2013), The British Dream: Successes and Failures of Post-war Immigration (London: Atlantic Books).

Gutman, A. and Taylor, C. (1994), Multiculturalism (Princeton: Princeton University Press). Hansen, R. (2000), Citizenship and Immigration in Postwar Britain (Oxford: Oxford University Press).

(2006), 'The Danish Cartoon Controversy: A Defence of Liberal Freedom', International Migration, 44(5): 7-16.

— and Gordon, J. (2014), 'Deficits, Democracy, and Demographics: Europe's Three Crises', West European Politics, 37(6): 1199-222.

Hero, R.E. and Preuhs, R.R. (2006), 'Multiculturalism and Welfare Policies in the USA: A State-level Comparative Analysis', in K. Banting and W. Kymlicka (eds), Multiculturalism and the Welfare State (New York: Oxford University Press): 121-51.

Hollifield, J.F., Martin, P.L. and Orrenius, P.M. (2014) (eds), Controlling Immigration: A Global Perspective, 3rd edn (Stanford: Stanford University Press).

IOM (2015), 'How the World Views Migration', International Organization for Migration, Geneva, www.iom.int/files/live/sites/iom/files/pbn/docs/How-theWorld-Views-Migration-Gallup-flyer.pdf. 
Jones, O. (2015), 'Charlie Hebdo: Norway Didn't Give into Anti-Semitism, nor Should France', The Guardian, 8 January, www.theguardian.com/commentisfree/2015/ jan/08/charlie-hebdo-norway-islamophobia-france-anders-breivik.

Joppke, C. (1998), Immigration and the Nation State: The United States, Germany, and Britain (Oxford: Clarendon).

- (2010), Citizenship and Immigration (Cambridge: Polity).

Kymlicka, W. (2009), 'The Multicultural Welfare State?', in P.A. Hall and M. Lamont (eds),

Successful Societies: How Institutions and Culture Affect Health (Cambridge: Cambridge University Press): 226-53.

Marrus, M. (1985), The Unwanted (New York: Oxford University Press).

Marshall, R. (2015), 'The (In)Secure Citizen: Islamophobia and the Natives of the Republic after Paris', in E.M. Iacobucci and S.J. Toope (eds), After the Paris Attacks: Responses in Canada, Europe, and Around the Globe (Toronto: University of Toronto Press): 43-53.

Martin, P. (2015), 'Economic Aspects of Migration', in C.B. Brettell and J.F. Hollifield (eds), Migration Theory: Talking across Disciplines (New York: Routledge): 90-109.

Miller, D. (2004), 'Immigrants, Nations, and Citizenship', unpublished paper presented to CRASSH conference, 'Migrants, Nations, and Citizenship', New Hall, Cambridge, 5-6 July.

(2005), 'Immigration: The Case for Limits', in A. Cohen and C. Wellman (eds), Contemporary Debates in Applied Ethics (Malden, MA: Blackwell Publishing): 193-206.

— (2008), 'Immigrants, Nations, and Citizenship', Journal of Political Philosophy, 16(4): 371-90.

Modood, T. (2006), 'The Liberal Dilemma: Integration or Vilification', Open Democracy website, 8 February, www.opendemocracy.net/faith-terrorism/liberal_dilemma_3249.jsp. (2015), 'In Remembering the Charlie Hebdo Attack we Must Not Forget the Responsibility that Goes With Free Speech', LSE Comment, blog, 12 January, http://blogs.lse.ac.uk/europpblog/2015/01/12/in-remembering-the-charlie-hebdoattack-we-must-not-forget-the-responsibility-that-goes-with-free-speech.

O'Leary, B. (2006), 'Liberalism, Multiculturalism, Danish Cartoons, Islamist Fraud, and the Rights of the Ungodly', International Migration, 44(5): 22-33.

O’Neil, B. (2015), 'Islamophobia is a Myth', National Review, 9 January, www.nationalreview. com/article/411371/islamophobia-myth-brendan-oneill.

OECD (2014), 'Is Migration Good for the Economy?', OECD, Paris, May, www. oecd.org/migration/mig/OECD\%20Migration\%20Policy\%20Debates\%20Numero \%202.pdf.

Putnam, R.D. (2007), 'E Pluribus Unum: Diversity and Community in the Twenty-First Century; the 2006 Johan Skytte Prize Lecture', Scandinavian Political Studies, 30: 137-74.

Sarrazin, T. (2012), Deutschland Schafft Sich ab: Wie Wir Unser Land aufs Spiel Setzen (Munich: Deutsche Verlags-Anstalt).

Schain, M. (2012), The Politics of Immigration in France, Britain and the United States: A Comparative Study, 2nd edn (Basingstoke: Palgrave Macmillan). 
Smith, J.P. and Edmonston, B. (1997), The New Americans: Economic, Demographic, and Fiscal Effects of Immigration (Washington, DC: National Academies Press).

UNHCR (2014), 'UNHCR Global Trends: Forced Displacement in 2014', www.unhcr. org/556725e69.html.

UN Population Division (2001), Replacement Migration: Is it a Solution to Declining and Ageing Populations? (New York: United Nations Secretariat).

Woldemicael, G. and Roderic, B. (2010), 'Fertility Behavior of Immigrants in Canada: British Trends', PSC Discussion Paper Series, 24(5): 1-30.

YouGov (2015), 'Health Overtakes Immigration as an Issue for Voters', YouGov, 15 April, https://yougov.co.uk/news/2015/04/15/health-tops-immigration-secondmost-important-issu.

Zong, J. and Batalova, J. (2015), Frequently Requested Statistics on Immigrants and Immigration in the United States (Washington, DC: Migration Policy Institute). 